\title{
Money Supply Determinants in Nepal: A Macro Analysis
}

\author{
Saraswoti Acharya Tiwari*
}

\begin{abstract}
This paper analyzes the major money supply determinants in Nepal in the past 10 years from FY 2004/05 - FY 20014/15. In this study monetary base is determined by two explanatory variables (i.e. NFA and NDC) and are called the 'proximate' determinants of the base money. Among the explanatory variables, the net foreign asset (NFA) is found as better determinant than net domestic assets (NDA) in Nepalese economy. For the analysis of determinants of money multiplier $(M M)$, the three explanatory variables i.e., reserve to total deposits ratio (r), time deposits to demand deposits ratio ( $t$ ) and currency to demand deposits ratio (c) have been used. The model applied in this study shows that explanatory variable of time deposits to demand deposits ratio is the best determinant of money multiplier. The reserve money (RM) is analyzed as the best determinant of money supply, net foreign assets (NFA) is the major determinant of reserve money and time deposits to demand deposits ratio is the significant determinant of money multiplier.
\end{abstract}

Key words: Money Supply Determinants, Money Multiplier, Monetary Base, Net Foreign Assets, Reserve Money, Net Domestic Assets, Proximate, Explanatory Variable.

\section{INTRODUCTION}

The Nepalese monetary economy is characterized by the existence of a large non-monetized sector, economic instability and lop sided financial market. Moreover, the rural economy is also dominated by the prevalence of cash over credit transactions. A large proportion of cash circulates in the economy but it does not take place in the bank deposits due to limited banking facilities as well as the lack of public awareness. A high proportion of total money stocks remains idle and an increase in investment outlays by the expansion of money supply tends to exert pressure on price level without increasing output. In this regard, Kurihara (1978:5) has stated that money is the most dynamic element in modern economy - a link between the present and future. Despite these, money is anything that is generally acceptable as a means of payment in the settlement of all transactions including debt [Gupta. 1982:3]. According to friedman - Schwarty, money supply is determined by three determinants high powered money $(\mathrm{H})$, the total deposits to reserve ratio (TD/R) and demand deposits to currency ratio (Pant, 1979:17). Cagans expressed the currency as a ratio to money $(\mathrm{C} / \mathrm{M})$ and reserve as a ratio to deposits $(\mathrm{R} / \mathrm{D})$. Burner and Meltzer also expressed the high powered money $(\mathrm{H})$ as the variable of the money stock called monetary base (Pant, 1979:17).

With regard to the determinants of money supply in Nepal, Gaudel (1994) analysis exhibited that the change in domestic credit has a positive impact on the expansion of money supply. Moreover, the continuously growing government budget deficit and financing it from external borrowing has helped to increase money supply via increase in net foreign assets. Besides, the efficacy of

\footnotetext{
* Mrs. Acharya is Teaching Faculty in Department of Economics , PN Campus. TU.
} 
monetary policy tends to show that it seems unable to control the growth rate of money supply in the desired level.

In this article, the three monetary aggregates such as reserve money $\left(\mathrm{R}_{\mathrm{M}}\right)$, narrow money $\left(\mathrm{M}_{1}\right)$ and broad money $\left(\mathrm{M}_{2}\right)$ have been used. According to the money multiplier theory, money is the function of reserve money and money multiplier. The general equation of money supply can be expressed as:

$$
\mathrm{M}_{\mathrm{S}}=\mathrm{m} \times \mathrm{R}_{\mathrm{M}}
$$

Where, $M_{S}=$ Money Supply, $m=$ Multiplier, $R_{M}=$ Reserve Money, Says that the determinants of money supply $\left(\mathrm{M}_{\mathrm{S}}\right)$ can be classified as:

i) Factors affecting reserve money $\left(\mathrm{R}_{\mathrm{M}}\right)$ i.e. net foreign assets (NFA) and net domestic assets (NAD)

ii) Factors affecting reserve money multiplier (m) are currency ratio, reserve ratio and the time deposits ratio.

There is still a debate of what is the appropriate level of money supply. It is said that the desired level of money supply is obtained by taking real GDP growth rate, income elasticity of money demand and inflation rates. Thus, the government or the central banks in most countries exercise monetary control measures.

Nepal Rastra Bank as a central bank of Nepal is solely responsible to manage money supply within a desirable limit. It has had to face certain limitations in controlling money supply. It has been formulating annual monetary policy to manage money supply in Nepal. The supply of money should be consistent with national economic growth. Otherwise, lower supply would have deflationary effects, and the higher supply would have inflationary consequences. Hence, this paper has studied the factors affecting money supply and their contributions in terms of their magnitude and direction.

The main objective of this study is to examine the determining factors of money supply in Nepal. The specific objectives are as follows:

i) To analyze the multiplier effect in the perspective of money supply determinants.

ii) To study and analyze the factors of high - powered money or reserve money.

iii) To ascertain high powered money as a significant determinant of money supply in Nepal.

\section{DATA AND METHODOLOGY}

This study is based on secondary sources. Data are adopted from the various Quarterly Economic Bulletins published by Nepal Rastra Bank, and Economic Survey published by the Ministry of Finance, Government of Nepal. This paper tries to analyze the money supply determinants in Nepal. It covers the period of 10 years from FY 2004/05 to FY 2014/15. To observe and analyze the determinants of money supply, the major factors, such as, monetary base (BM) and money multiplier (MM) are taken as a prominent determinants. In this context, Net Foreign Assets (NFA), Net Domestic Assets (NDA), Reserve to Total Deposits Ratio (r), Time Deposits to Demand Deposits ratio $(t)$ and Currency to Demand Deposits ratio (c) have been considered as independent variables.

In order to estimate causal relationships between money supply $\left(\mathrm{M}_{\mathrm{S}}\right)$ with its determining factors, a log linear model has been applied in the following form:

$$
\ln \mathrm{M}_{\mathrm{S}}=\alpha+\beta_{1} \ln \mathrm{BM}+\beta_{2} \ln \mathrm{MM}+\mu
$$

Where $\ln M_{S}=\log$ of money supply, $\alpha$ is constant, $\beta_{1}$ and $\beta_{2}$ are the coefficients of base 
money and money multiplier respectively and ' $\mu$ ' is a disturbance term: BM and MM refer log value of the independent variables.

Furthermore, to analyze the causal relationship between the dependent and independent variables of monetary base and money multiplier two separate models are applied in the following form:

$$
\ln \mathrm{BM}=\alpha+\beta_{1} \ln \mathrm{NFA}+\beta_{2} \ln \mathrm{NDA}+\mu
$$

And,

$$
\ln \mathrm{MM}=\alpha+\beta_{1} \ln r+\mathrm{B}_{2} \operatorname{lnt}+\mathrm{B}_{3} \ln \mathrm{c}+\mu
$$

Where, $\beta_{1}, \beta_{2}$ and $\beta_{3}$ represent the degree of dependent variables. The terminologies such as NFA, NDA, r, t, c refer net foreign assets, net domestic assets, reserve ratio, time deposits ratio and currency ratio respectively.

\section{RESULTS AND DISCUSSION}

\section{Money Supply Determinants in Nepal}

Currencies, demand deposits, time deposits, net domestic assets and net foreign assets of the banking system are the major factors affecting money supply in Nepal.

Generally, money supply is determined by two factors i.e., base money (BM) and money multiplier (MM). It also implies that the two proximate determinants of money supply are reserve money and money multiplier. Reserve money is determined by the, net foreign assets and net domestic assets having their positive relationship is illustrated in the following table 1.

\begin{tabular}{|c|c|c|c|c|}
\hline & \multirow[t]{3}{*}{ Determinants } & \multicolumn{2}{|c|}{ Mid-July } & \multirow{3}{*}{$\begin{array}{c}\text { \% change } \\
\text { within } 10 \text { yrs period }\end{array}$} \\
\hline & & & & \\
\hline & & 2004 & 2014 & \\
\hline \multirow[t]{3}{*}{1.} & Narrow Money $\left(\mathrm{M}_{1}\right)$ & 94.0 & 354.8 & 227.45 \\
\hline & Currency held by the public & 63.2 & 227.5 & \\
\hline & Demand deposits held by public & 30.8 & 127.3 & \\
\hline \multirow[t]{6}{*}{2.} & Net Domestic Assets (NDA) (Dc-Co) & 168.5 & 966.7 & 473.71 \\
\hline & a. Domestic credit (Dc) & 251.1 & 1312.6 & \\
\hline & Net claims on government & 62.3 & 140.3 & \\
\hline & Claims on government enterprises & 16.3 & 11.9 & \\
\hline & Claims on private sector & 172.5 & 1150.8 & \\
\hline & b. Net capital and other items (co) & 82.6 & 345.9 & \\
\hline 3. & Net Foreign Assets (NFA) & 108.8 & 599.2 & 450.74 \\
\hline 4. & $\begin{array}{l}\text { Broad Money }\left(\mathrm{M}_{2}\right) \\
(\mathrm{NDA}+\mathrm{NFA})=\mathrm{M}_{1}+\text { Time Deposits }\end{array}$ & 277.3 & 1566.0 & 464.73 \\
\hline 5. & Time Deposits & 183.3 & 1211.1 & 560.72 \\
\hline \multirow[t]{6}{*}{6.} & Reserve money (RM) & 94.4 & 436.6 & \\
\hline & Currency held by private sector & 63.2 & 227.5 & \\
\hline & Currency held by commercial banks & 4.3 & 41.1 & \\
\hline & Deposits of private sector & 2.7 & 11.7 & \\
\hline & Deposits of Commercial banks & 24.2 & 156.2 & \\
\hline & Total Money Supply & 371.3 & 1920.8 & 417.32 \\
\hline
\end{tabular}

Table 1: Determinants of Total Money Supply

Table 1 depicts the situation of different expansionary and contractionary factors that determine money supply in Nepal. The net foreign assets witnessed an increase of $450.74 \%$ in July 2014 
compared with the same period of 2004. On average, it was increased by $45.07 \%$ per year. However, domestic credit which has a positive impact on the net domestic assets increased by $473.71 \%$ during the period of 10 years. On average, it was also increased by $47.37 \%$ per year. Where net domestic assets is the difference of domestic credit (Dc) over net capital and other items (Co) Thus, domestic credit clearly shows that the credit to the government and private sectors having the components of net domestic assets had significant impact on net domestic assets . However, claims on government enterprises had negative impact on net domestic assets.

Among the contractionary factors affecting money supply, time deposits as the principal factor observed a growth rate of $560.72 \%$ in the mid July 2014 as compared to the same period of 2004 . Similarly, the capital and other items also increased by $318.77 \%$ during the FY 2014/15 in comparison to the same period of FY 2004/05. However, these rates of contractionary factors seems to be insignificant in giving counter balance to the money supply.

\section{Determinants of Money Multiplier}

Money Multiplier (MM) is a function of three behavioral asset ratios, such as currency to demand deposits ratio (c), time deposits to demand deposits ratio (t) and reserve to demand deposits ratio (r). The value of money multiplier comes out by the interaction of the three sectors i.e. the public, the commercial banks and the cental bank.

Money Multiplier (MM) for narrow money and broad money has been illustrated in table 2 .

Table 2: Determinants of Money Multiplier

\begin{tabular}{|c|c|c|}
\hline $\begin{array}{c}\text { Year } \\
\text { Mid-July }\end{array}$ & $\begin{array}{c}\text { Narrow Money Multiplier } \\
\left(\mathrm{MM}_{1}\right)\end{array}$ & $\begin{array}{c}\text { Broad Money Multiplier } \\
\left(\mathrm{MM}_{2}\right)\end{array}$ \\
\hline 2004 & 0.60 & 1.71 \\
2005 & 0.61 & 1.79 \\
2006 & 0.60 & 1.84 \\
2007 & 0.63 & 1.95 \\
2008 & 0.63 & 2.02 \\
2009 & 0.61 & 1.96 \\
2010 & 0.61 & 2.0 \\
2011 & 0.72 & 2.97 \\
2012 & 0.54 & 2.31 \\
2013 & 0.55 & 2.39 \\
2014 & 0.53 & 2.36 \\
\hline
\end{tabular}

Source: NRB, Quarterly Economic Bulletin, Vol 48, mid July 2014

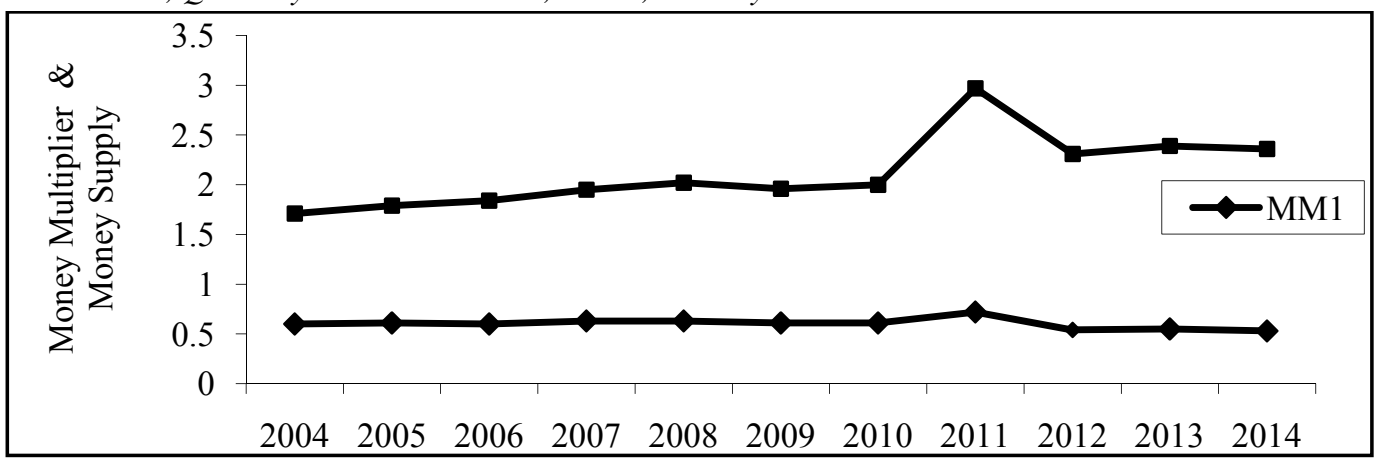




\section{Figure 1: Money Multiplier for Narrow and Broad Money}

The value of narrow money multiplier was 0.60 in 2004 and it increased to 0.63 in $2007 \& 2008$. The peak value was 0.72 in 2011 . However, it fell to 0.50 in 2014 . On average it was found 0.60 within the study period. The analysis also showed that there were intermittent ups and down trend in narrow money multiplier. This may be due to inconsistency in currency ratio. The value of money multiplier for broad money was 1.71 in 2004 and it increased to 2.02 in 2008 . The highest value within the study period was found 2.97 in 2011 . On average, it was 2.03 for the whole study period. The increasing trend of broad money multiplier was mainly due to increase in time deposits ratio.

As shown in figure 1, the value of narrow money multiplier was approximately 1 . It remained more or less stable, while the money multiplier for $\mathrm{M}_{2}$ was in the range of 1.5 to 3 .

\section{Regression results}

It is stated that the money multiplier is a significant major determinant of money supply in Nepal, keeping other factors as constants. To establish this fact numerically, money supply measured in billion rupees is regressed with its determinants and the results are depicted below.

$\begin{array}{llll}\mathrm{LnMM}_{1}= & 0.057 & -0.564 \ln r & 0.080 \operatorname{lnc} \\ \text { SEE } & (0.386) & (0.314) & (0.342) \\ \mathrm{t} \text { - value } & 0.147 & -1.795^{*} & 0.233^{*} \\ \mathrm{R}=0.536 & \mathrm{R}^{2}=0.287 & \overline{\mathbf{R}}^{2}=0.109 & \mathrm{SE}\left(\mathrm{MM}_{1}, \mathrm{r} \& \mathrm{c}\right)=0.08477\end{array}$

And,

\begin{tabular}{|c|c|c|c|c|}
\hline $\begin{array}{l}\operatorname{lnMM} M_{2}= \\
\mathrm{SEE}\end{array}$ & $\begin{array}{c}0.293 \\
(0.529)\end{array}$ & $\begin{array}{l}-0.286 \operatorname{lnr} \\
(0.477)\end{array}$ & $\begin{array}{l}-0.722 \operatorname{lnc} \\
(0.488)\end{array}$ & $\begin{array}{l}+0.622 \operatorname{lnt} \text {-------- (2) } \\
(0.206)\end{array}$ \\
\hline t-value & 0.554 & -0.600 & -1.479 & 3.025 \\
\hline $\mathrm{R}=0.906$ & $\mathrm{R}^{2}=0.820$ & $\overline{\mathbf{R}}^{2}=0.730$ & $\mathrm{M}_{2} \cdot \mathrm{r}, \mathrm{c} \&$ & 08595 \\
\hline
\end{tabular}

* Significant at $1 \%$ level of significance

The regression results in model (1) reveal that there seems insignificant relationship between the narrow money multiplier (MM) with currency (lnc) ratio and reserve ratio (lnr). The regression outcome indicates that the values of currency ratio the coefficient of reserve ratio are significant, while the coefficient of reserve ratio as an independent variable is insignificant at $1 \%$ level of significance. However, for board money multiplier $\left(\mathrm{MM}_{2}\right)$ both reserve ratio and currency ratio as independent variables are insignificant at $1 \%$ level of significance, but the time deposits ratio in model (2) as an independent variable is found significant at $1 \%$ level of significance. The variation explained by the regression $\mathrm{R}^{2}$ is near to unity. Thus, the regression model is best fitted. Moreover, the overall performance of the regression line is found significant by observing the value of $\mathrm{F}$ static.

\section{CONCLUSION AND SUGGESTION}

To conclude, Reserve money has been the dominant determinant of money supply for both narrow money $\left(\mathrm{M}_{1}\right)$ and broad money $\left(\mathrm{M}_{2}\right)$. However, the value of money multiplier is statistically insignificant in case of narrow money, but it is significant in broad money. Since reserve money is largely policy determined variable, the monetary authority can regulate the total volume of money supply by means of its proper management and effective implementation. In recent time, the 
increasing trend of the foreign assets, which is not in the control of Nepal Rastra Bank, as a central bank, may arise some difficulties to control reserve money in appropriate direction because net foreign assets depend on the balance of payments situation and net credit to government depends upon the government budgetary position. Thus, controlling money supply through changing reserve money and money multiplier is not strong. It implies that the growth rate of money supply is found to be inflationary in Nepal.

On the basis of the finding of the study, it will be suggested that to attain the money supply as targeted level, determining factors of money supply should be changed in desired level.

\section{References}

Friedman, M. \& Schawartz, A.J. (1963). A Monetary History of the United States 1867-1960. USA: Princeton.

Gaudel Y.S. (1994) Money Supply Determinants in Nepal: An Economic Analysis, Economic Literature Vol (1) January-June, PP 18-24.

Gupta, S.B. (2000). Monetary Economics: Theory and Policy, New Delhi: S. Chand and Company.

Kurihara, K.K. (1978). Monetary Theory and Public Policy, New Delhi: Kalyani Publishers.

NRB (2014), Nepal Rastra Bank, Quarterly Economic Bulletin, Vol (48), Mid-July.

Pant K.D. (1997). An Econometric Study of Money Supply in Nepal. Unpublished Dissertation Submitted to the Central Department of Economics, Kirtipur, Kathmandu, Nepal. 